\title{
CARD9 wt Allele
}

National Cancer Institute

\section{Source}

National Cancer Institute. CARD9 wt Allele. NCI Thesaurus. Code C131149.

Human CARD9 wild-type allele is located in the vicinity of $9 q 34$ and is approximately $12 \mathrm{~kb}$ in length. This allele, which encodes caspase recruitment domain-containing protein 9, plays a role in both the regulation of apoptosis and innate immune responses.. 